Gut, 1978, 19, 492-496

\title{
Serum bile acids in hepatobiliary disease
}

\author{
IAN A. D. BOUCHIER AND C. R. PENNINGTON \\ From the Department of Medicine, Ninewells Hospital and Medical School, Dundee, Scotland
}

SUMMARY We review the estimation of total and individual serum bile acids to detect the presence and nature of hepatobiliary disease. The different methods for measuring serum bile acids are discussed.

In clinical practice, the term 'liver function test' is applied to a variety of serum measurements that are merely potential markers of hepatobiliary disease. Unfortunately, they all lack sensitivity and specificity, and alone are inefficient in detecting the presence and defining the nature of hepatobiliary disease (Winkel et al., 1975). Although the importance of these tests has declined with the development of more sophisticated techniques of hepatobiliary investigation, the concept remains attractive because of the safety, rapidity, and economy of such serum measurements. Hence the search for more suitable serum tests for liver disease continues.

Bile acids are synthesised and conjugated by hepatic microsomal, mitochondrial, and lysosomal enzymes (Danielsson and Sjövall, 1975). The enterohepatic circulation normally ensures that $20 \mathrm{~g}$ of bile acids pass through the liver each day, during which time 4 to $5 \mathrm{~g}$ are newly synthesised to compensate for faecal loss (Heaton, 1972; Hofmann, 1977). Hepatobiliary disease may therefore be associated with changes in bile acid metabolism which are reflected in altered serum bile acid concentrations. It has frequently been suggested that the measurement of changes in serum bile acids might indicate the presence, and possibly the nature, of liver and biliary disease.

Early studies sought to differentiate intrahepatic from extrahepatic cholestasis on the basis of altered proportions of individual bile acids; later work investigated the value of measuring the total serum bile acids in the detection of hepatic disease. Many different methods were used in the course of these studies, and provided different information. Furthermore, until recently, accurate measurement of the low bile acid concentrations found in normal subjects could not be achieved.

\section{Methods}

The spectrophotometric methods employed in the early studies lacked sensitivity and specificity. Some workers used thin layer chromatography and fluorimetry for measurement of individual serum bile acids, but adequate separation of dihydroxy bile acids was not possible (Panveliwalla et al., 1970).

There are currently three approaches to serum bile acid estimations. First, gas liquid chromatography involves lengthy chemical modification of specimens for analysis, but provides information about all the major bile acids. Second, the enzymatic fluorimetric method is simple and rapid, but provides only an approximate value of the concentrations of total serum bile acids. Third, radioimmunoassay is a rapid method for measuring individual bile acid conjugates, but a different assay is required for each one.

The first application of gas liquid chromatography to the measurement of serum bile acids was by Sandberg et al. (1965). Improvements were introduced by Roovers et al. (1968). Enzyme hydrolysis replaced alkaline hydrolysis, which is known to destroy bile acids (Levin et al., 1961), and an internal standard solved the problem of procedural losses and standardisation of the gas liquid chromatography injections. Further modifications were reported by Henegouwen et al. (1974), and, more recently, Ross et al. (1977) demonstrated the accurate measurement of serum bile acids in the normal range using only $2 \mathrm{ml}$ of serum.

The enzymatic fluorimetric method was introduced by Iwata and Yamasaki (1964). It depends upon the enzymatic dehydrogenation of the $3 \alpha$ hydroxyl group which is common to all the major bile acids found in man, and is based on the formation of NADH from NAD in the presence of bile acids, the enzyme $3 \alpha$ dehydrogenase, and a ketone trapping agent. NADH is measured by fluorimetry as first described by Murphy et al. (1970). A liquid solid extraction with Amberlyte XAD2 resin improved the method (Schwartz et al., 1974), but a lack of specificity was suggested by control serum bile acid values which were twice 492 
those found by gas liquid chromatography. Some improvement, however, followed the introduction of a purified enzyme (Fausa, 1975). The use of $7 \alpha$ hydroxysteroid dehydrogenase has been used to measure the total primary bile acids (Macdonald, 1976; Fausa and Skålhegg, 1977). The $7 \alpha$ hydroxyl group is common only to the primary bile acids.

The first radioimmunoassay for conjugated cholyl bile acids was reported by Simmonds et al. (1973). A similar method was described by Matern et al. (1976), who advocated the preliminary extraction of the bile acids from serum using XAD2 resin. A method for chenodeoxycholic acid conjugates was developed by Schalm et al. (1977). The radioimmunoassay methods for conjugates of cholic, chenodeoxycholic, deoxycholic, and sulpholithocholic acids, described by Demers and Hepner (1976), were notable for the absence of crossreaction between glycine and taurine conjugates. Finally, the recent report of an $\mathbf{I}^{\mathbf{1 2 5}}$ radioimmunoassay for primary conjugated bile salts (Spenney et al., 1977) promised a cheaper method. The Y emission avoided the tritium based assay, but control values for cholylglycine $(3.47 \pm 2 \cdot 16 \mu \mathrm{mol} / \mathrm{l})$ appeared high.

\section{Early clinical studies of serum bile acids}

An early study by Sherlock and Walshe (1948) investigated the possibility that blood cholate estimation in jaundiced patients might differentiate extrahepatic obstruction from parenchymatous liver disease. Unfortunately, cholate values were found to be similar in both groups of patients, and thus failed to distinguish between potential disorders of synthesis and excretion. Many patients, especially those with cirrhosis, had normal cholate values. This was probably due to the use of a nonspecific method (Josephson, 1935) which resulted in a normal range 30 -fold greater than that defined by present workers using improved techniques (Simmonds et al., 1973; Matern et al., 1976; Pennington et al., 1978b).

The simultaneous measurement of trihydroxy and dihydroxy bile acids by spectrophotometric methods focused attention on the apparent value of the trihydroxy:dihydroxy bile acid ratio in differential diagnosis. Rudman and Kendall (1957) observed that trihydroxy bile acids could not be measured in their cirrhotic patients; the ratio was less than one in patients with chronic hepatitis, and exceeded one in a mixed group of patients with cholestasis. Similar conclusions were drawn by Carey (1958); and other workers considered that the low ratio in cirrhosis signified a poor prognosis (Osborn et al., 1959).

\section{Recent studies}

TOTAL SERUM BILE ACIDS AND THE DETECTION OF HEPATOBILIARY DISEASE

The first convincing evidence that serum bile acid measurement might be a more sensitive index for the presence of liver disease was provided by Frosch and Wagener (1967). Abnormal values of serum bile acids were observed to correspond with histological abnormalities in patients convalescing from viral hepatitis who had normal conventional liver function tests. Kaplowitz et al. (1973) first suggested that measuring serum bile acids two hours after a meal was the method of choice for detecting hepatobiliary disease. All 26 of their patients had raised postprandial total serum bile acids, whereas the fasting values were normal in 10 patients. In another study, total postprandial serum bile acids were increased in all 30 patients with histological evidence of liver disease. The fasting serum bile acids were normal in three patients, and normal values for bilirubin, alkaline phosphatase, and aspartate aminotransferase were found in at least seven patients (Barnes et al., 1975). It is notable, however, that the former study excluded patients with non-functioning gallbladders, and the methods employed in both studies were insufficiently sensitive to discriminate between fasting and postprandial serum bile acid values in normal subjects. The latter criticism was not applicable to another study (Fausa and Gjone, 1976), in which it was claimed that estimations of fasting and postprandial serum bile acids were superior to conventional liver function tests. Unfortunately, the analysis of the data merely demonstrated that the overall increase in the values of serum bile acids exceeded that for other indices. When the data were reanalysed on the basis of frequency of abnormal response, the fasting values of serum bile acids were abnormal significantly less frequently, and the postprandial values were abnormal significantly more frequently, than the conventional liver function tests. Another report observed that the postprandial total serum bile acids remained raised after conventional liver function tests had returned to the normal range in subjects recovering from an overdose of paracetamol (Hamlyn et al., 1977). In our own studies we have found no difference between the total fasting or postprandial serum bile acids, aspartate aminotransferase, and gamma glutamyltranspeptidase in the detection of anicteric patients with occult hepatic disease (Pennington et al., 1977a).

The above studies measured conjugated and inconjugated individual and/or total serum bile acids. Korman et al. (1974) found that the measurement of cholyl conjugates by radioimmunoassay was 
very useful for the early detection of relapse in patients with chronic active hepatitis. Demers and Hepner (1975) specifically measured glycine conjugates of the three major bile acids and sulpholithocholic acid, and found that the latter was the only bile acid with a raised value in all the patients they studied.

A different approach was adapted by the Mayo group, who investigated the plasma disappearance of intravenous ${ }^{14} \mathrm{C}$ cholylglycine in patients with histological evidence of hepatobiliary disease ( $\mathrm{La}$ Russo et al., 1974). Reduced plasma clearance of ${ }^{14} \mathrm{C}$ cholylglycine was a better way of identifying patients than the measurement of fasting serum cholylglycine. Subsequently, Thjodleifsson et al. (1977) observed that the estimation of total postprandial serum bile acids was a better method than the intravenous bile acid tolerance test in the detection of hepatic disease.

\section{SERUM BILE ACIDS AND NATURE OF}

\section{HEPATIC DISEASE}

Several studies have demonstrated a proportionate reduction in serum deoxycholic acid in patients with all forms of hepatobiliary disease (Makino et al., 1969; Pennington et al., 1977a). Thus the trihydroxy: dihydroxy bile acid ratio, described in earlier studies, is equivalent to the cholic:chenodeoxycholic acid ratio, which will be described as the primary bile acid ratio.

Some workers have advocated the use of this ratio in differential diagnosis. Makino et al. (1969) observed primary bile acid ratio values of less than 1.5 in 26 out of 30 patients with portal cirrhosis. Values were greater than 1.5 in 17 out of 18 patients with obstructive jaundice. Similar findings were reported by Neale et al. (1971). In both studies the normal range of the primary bile acid ratio was large, and overlapped the values for the different diagnostic groups. Clearcut separation of cirrhotics, from controls, from patients with large duct obstruction, on the basis of this ratio, has recently been reported (Pennington et al., 1977a). Unfortunately, there is no evidence that this ratio, or any other bile acid measurement, can separate patients with intrahepatic cholestasis from those with extrahepatic cholestasis in adult practice. Javitt et al. (1973) considered that the ratio was useful in distinguishing biliary atresia (low values) from intrahepatic cholestatic syndromes (high values) in infants. This observation, however, has been disputed (Mowat, 1976).

The primary bile acid ratio has also been applied to the staging of disease. Patients with primary biliary cirrhosis were noted to have falling values as their disease progressed, and ratios of less than one were associated with terminal illness (Bloomer et al., 1976). In a study of alcoholic liver disease, the ratio was low in active cirrhosis, and high in patients with inactive cirrhosis (Milstein et al., 1976). Similarly, the ratio was noted to increase from abnormally low values as patients with chronic active hepatitis entered remission (Pennington, 1977). In the course of viral hepatitis it has been reported to increase (Pennington et al., 1978c) or decrease (Erb et al., 1972).

Makino et al. (1969) reported that half the serum bile acids in normal subjects were unconjugated. The conjugated fraction increased in patients with extrahepatic obstruction, and an increase in the unconjugated fraction was observed in patients with cirrhosis. The study by Neale et al. (1971), however, demonstrated that most serum bile acids were conjugated, and the state of conjugation with glycine or taurine was variable. Several studies have reported that a small proportion of serum bile acids are sulphated (Makino et al., 1972; Stiehl, 1974; Makino et al., 1975; - Henegouwen et al., 1976). No evidence has been presented to suggest that the measurement of sulphates is of diagnostic value.

The ability of the liver to conjugate intravenous ${ }^{14} \mathrm{C}$ cholic acid has been used to assess the potential recovery of patients in grade IV coma from acute hepatic failure (Horak et al., 1976).

\section{Pathological mechanisms}

Many factors influence serum bile acid values, of which intestinal absorption plays an important part (La Russo et al., 1974). In health the primary bile acid pool sizes are similar and the predominance of chenodeoxycholic acid in the serum of healthy subjects may reflect more rapid absorption of chenodeoxycholic acid (Angelin et al., 1976), and the preferential hepatic clearance of cholic acid (Cowen et al., 1975).

An increase in serum bile acid values will be expected in the presence of portasystemic shunting, or damaged hepatocytes which are unable to extract the bile acids from the portal blood. It is also apparent that bile acids 'leak' directly from the liver to the systemic circulation, as very high serum bile acid concentrations are found in patients with extrahepatic obstruction (Makino et al., 1969; Pennington et al., 1977a).

It is known that the cholic acid pool is decreased in cirrhotic patients (McCormick et al., 1973). This may be due to a failure of $12 \alpha$ hydroxylation in the major synthetic pathway, or a possible increase in the relative role of an alternative pathway (Mitropoulos and Myant, 1967) from which chenodeoxycholic 
acid may be derived (Anderson et al., 1972). Proportionately more cholic acid has been described in livers following large duct obstruction (Greim et al., 1972). Unfortunately, many aspects of bile acid metabolism which influence serum bile acid values are poorly understood.

\section{Conclusions}

During the past 30 years papers have appeared with increasing frequency as the technical difficulties posed by serum bile acid measurements have been partially resolved. Early reports suggested that the measurement of total serum bile acids was unhelpful, but this reflected a lack of specificity in the methods used. Subsequently, the measurement of total and single serum bile acids has been acclaimed as the most sensitive means of detecting occult liver disease. More recently, the measurement of total values two hours after a meal has been advocated, and has been found to be superior to an intravenous bile acid tolerance test.

Initial reports that changes in the bile acid ratios reflected the nature of hepatobiliary disease aroused interest in the application of these indices in differential diagnosis. Subsequent work confirmed these trends, the clinical value of which remains to be established.

The assumption has been made that serum bile acids have the advantage of specificity compared to other liver function tests. This assumption requires examination. High serum bile acid values have been reported in patients with small bowel colonisation (Lewis et al., 1969); abnormal serum bile acids have been described in hyperlipidaemia (Pennington et al., 1977a), and changing serum bile acids have been noted with alteration of the dietary vitamin C (Kallner, 1977). The influence of drugs which alter hepatic metabolism or bind bile acids in the bowel lumen merit further study. The possibility that measurement of the serum bile acids may be useful in monitoring gallbladder and intestinal function requires investigation.

After 30 years, and many clinical and laboratory studies, further work is required to establish the place of serum bile acid measurement in clinical practice.

We wish to thank Dr P. E. Ross, Mr J. Murison, Miss A. McDonald for expert technical assistance, and Mrs N. Spain for typing the manuscript.

\section{References}

Anderson, K. E., Kok, E., and Javitt, N. B. (1972). Bile acid synthesis in man: metabolism of 7 -hydroxycholesterol${ }^{14} \mathrm{C}$ and 26 hydroxycholesterol- ${ }^{3} \mathrm{H}$. Journal of Clinical
Investigation, 51, 112-117.

Angelin, B., Einarsson, K., and Hellström, K. (1976). Evidence for the absorption of bile acids in the proximal small intestine of normo- and hyperlipidaemic subjects. Gut, 17, 420-425.

Barnes, S., Gallo, G. A., Trash, D. B., and Morris, J. S. (1975). Diagnostic value of serum bile acid estimations in liver disease. Journal of Clinical Pathology, 28, 506-509.

Bloomer, J. R., Allen, R. M., and Klatskin, G. (1976). Serum bile acids in primary biliary cirrhosis. Archives of Internal Medicine, 136, 57-61.

Carey, J. B., Jr. (1958). The serum trihydroxy-dihydroxy bile acid ratio in liver and biliary tract disease. Journal of Clinical Investigation, 37, 1494-1503.

Cowen, A. E., Korman, M. G., Hofmann, A. F., and Cass, O. W. (1975). Metabolism of lithocholate in healthy man. 1. Biotransformation and biliary excretion of intravenously administered lithocholate, lithocholyglycine, and their sulfates. Gastroenterology, 69, 59-66.

Danielsson, H., and Sjövall, J. (1975). Bile acid metabolism. Annual Review of Biochemistry, 44, 233-253.

Demers, L. M., and Hepner, G. W. (1975). Serum bile acids in patients with hepatobiliary disease. Gastroenterology, 68, 881.

Demers, L. M., and Hepner, G. (1976). Radioimmunoassay of bile acids in serum. Clinical Chemistry, 22, 602-606.

Erb, W., Schreiber, W. E., and Walczak, M. (1972). Gaschromatographische Untersuchengen der Serumgallensäuren: Methodik sowie Ergebnisse bei Patienten mit akuter Hepatitis. Zeitschrift für Gastroenterologie, 10, 349-358.

Fausa, O. (1975). Quantitative determination of serum bile acids using a purified $3 a$ hydroxysteriod dehydrogenase. Scandinavian Journal of Gastroenterology, 10, 747-752.

Fausa, O., and Gjone, E. (1976). Serum bile acid concentrations in patients with liver disease. Scandinavian Journal of Gastroenterology, 11, 537-543.

Fausa, O., and Skålhegg, B. A. (1977). Quantitative determination of serum bile acids using a $7 a$ hydroxysteroid dehydrogenase. Scandinavian Journal of Gastroenterology, 12, 441-447.

Frosch, B., and Wagener, H. (1967). Quantitative determination of conjugated bile acids in serum in acute hepatitis. Nature, 213, 404-405.

Greim, H., Trülzsch, D., Czygan, P., Rudick, J., Hutterer, F., Schaffner, F., and Popper, H. (1972). Mechanism of cholestasis. 6. Bile acids in human livers with or without biliary obstruction. Gastroenterology, 63, 846-850.

Hamlyn, A. N., Douglas, A. P., James, O, F. W., Lesna, M., and Watson, A. J. (1977). Liver function and structure in survivors of acetaminophen poisoning. American Journal of Digestive Diseases, 22, 605-610.

Heaton, K. W. (1972). The enterohepatic circulation: the life cycle of bile salts. In Bile Salts in Health and Disease, pp. 58-81. Churchill Livingstone: Edinburgh.

Henegouwen, Van Berge, G. P., Ruben, A., and Brandt, K. H. (1974). Quantitative analysis of bile acids in serum and bile using gas-liquid chromatography. Clinica Chimica Acta, 54, 249-261.

Henegouwen, Van Berge, G. P., Brandt, K. H., Eyssen, H., and Parmentier, G. (1976). Sulphated and unsulphated bile acids in serum, bile, and urine of patients with cholestasis. Gut, 17, 861-869.

Hofmann, A. F. (1977). The enterohepatic circulation of bile acids in man. Clinics in Gastroenterology, 6, 3-24.

Horak, W., Waldram, R., Murray-Lyon, I. M., Schuster, E., and Williams, R. (1976). Kinetics of $\left[{ }^{14} \mathrm{C}\right]$ cholic acid in fulminant hepatic failure: a prognostic test. Gastroenterology, 71, 809-813.

Iwata, T., and Yamasaki, K. (1964). Enzymatic determina- 
tion and thin layer chromatography of bile acids in blood. Journal of Biochemistry, 56, 424-431.

Javitt, N. B., Morrissey, K. P., Siegel, E., Goldberg, H., Gartner, L. M., Hollander, M., and Kok, E. (1973). Cholestatic syndromes in infancy: diagnostic value of serum bile acid pattern and cholestyramine administration. Paediatric Research, 7, 119-125.

Josephson, B. (1935). The determination of cholic acids in blood. Biochemical Journal, 29, 1519-1524.

Kallner, A. (1977). Serum bile acids in man during vitamin C supplementation and restriction. Acta Medica Scandinavica, 202, 283-287.

Kaplowitz, N., Kok, E., and Javitt, N. B. (1973). Postprandial serum bile acid for the detection of hepatobiliary disease. Journal of the American Medical Association, 225, 292-293.

Korman, M. G., Hofmann, A. F., and Summerskill, W. J. H. (1974). Assessment of activity in chronic active liver disease. New England Journal of Medicine, 290, 1399-1402.

La Russo, N. F., Korman, M. G., Hoffman, N. E., and Hofmann, A. F. (1974). Intestinal absorption-the major determinant of serum bile acids in patients with normal liver function. Gastroenterology, 67, 806 (Abstract).

Levin, S. J., Irvin, J. L., and Johnston, C. G. (1961). Spectrofluorometric determination of total bile acids in bile. Analytical Chemistry, 33, 856-860.

Lewis, B., Panveliwalla, D., Tabaqchali, S., and Wootton, I. D. P. (1969). Serum-bile-acids in the stagnant-loop syndrome. Lancet, 1, 219-220.

McCormick, W. C., III, Bell, C. C., Jr., Swell, L., and Vlahcevic, Z. R. (1973). Cholic acid synthesis as an index of the severity of liver disease in man. Gut, 14, 895-902.

Macdonald, I. A. (1976). Enzymatic analysis of bile acids. Clinical Biochemistry, 9, 153-154.

Makino, I., Hashimoto, H., Shinozaki, K., Yoshino, K., and Nakagawa, S. (1975). Sulfated and non-sulfated bile acids in urine, serum and bile of patients with hepatobiliary diseases. Gastroenterolvgy, 68, 545-553.

Makino, I., Nakagawa, S., and Mashimo, K. (1969). Conjugated and unconjugated serum bile acid levels in patients with hepatobiliary diseases. Gastroenterology, 56, 10331039.

Makino, I., Nakagawa, S., Shinozaki, K., and Mashimo, K. (1972). Sulfated and nonsulfated bile acids in human serum. Lipids, 7, 750-752.

Matern, S., Krieger, R., and Gerok, W. (1976). Radioimmunoassay of serum conjugated cholic acid. Clinica Chimica Acta, 72, 39-48.

Milstein, H. J., Bloomer, J. R., and Klatskin, G. (1976). Serum bile acids in alcoholic liver disease. American Journal of Digestive Diseases, 21, 281-285.

Mitropoulos, K. A., and Myant, N. B. (1967). The formation of lithocholic acid, chenodeoxycholic acid, and $\alpha$ and $\beta$ muricholic acids from cholesterol incubated with rat liver mitochondria. Biochemical Journal, 103, 472-479.

Mowat, A. P. (1976). Liver disease in infants and children In Recent Advances in Gastroenterology 3, pp. 261-269. Edited by Ian A. D. Bouchier, Churchill Livingstone: Edinburgh and London.

Murphy, G. M., Billing, B. H., and Baron, D. N. (1970). A fluorimetric and enzymatic method for the estimation of total serum bile acids. Journal of Clinical Pathology, 23, 594-598.
Neale, G., Lewis, B., Weaver, V., and Panveliwalla, D. (1971). Serum bile acids in liver disease. Gut, 12, 145-152.

Osborn, E. C., Wootton, I. D. P., Da Silva, L. C., and Sherlock, S. (1959). Serum-bile-acid levels in liver disease. Lancet, 2, 1049-1053.

Panveliwalla, D., Lewis, B., Wootton, I. D. P. and Tabaqchali, S. (1970). Determination of individual bile acids in biological fluids by thin-layer chromatography and fluorimetry. Journal of Clinical Pathology, 23, 309-314.

Pennington, C. R. (1977). Studies on Serum Bile Acids. M.D. Thesis: University of Manchester.

Pennington, C. R., Ross, P. E., and Bouchier, I. A. D. (1977a). Serum bile acids in the diagnosis of hepatobiliary disease. Gut, 18, 903-908.

Pennington, C. R., Ross, P. E., Bateson, M. C., and Bouchier, I. A. D. (1978a). Serum bile acids in patients with hyperlipidaemia. Journal of Clinical Pathology, 31, 58-62

Pennington, C. R., Ross, P. E., and Bouchier, I. A. D. (1978b). Fasting and postprandial serum bile acid concentrations in normal persons using an improved GLC. method. Digestion. 17, 56-62.

Pennington, C. R., Ross, P. E., and Bouchier, I. A. D. (1978c). Serum bile acids in patients with viral hepatitis. Scandinavian Journal of Gastroenterology. 13, 77-80.

Roovers, J., Evrard, E., and Vanderhaeghe, H. (1968). An improved method for measuring human blood bile acids. Clinica Chimica Acta, 19, 449-457.

Ross, P. E., Pennington, C. R., and Bouchier, I. A. D. (1977). Gas-liquid chromatographic assay of serum bile acids. Analytical Biochemistry, 80, 458-465.

Rudman, D., and Kendall, F. E. (1957). Bile acid content of human serum. I. Serum bile acids in patients with hepatic disease. Journal of Clinical Investigation, 36, 530-537.

Sandberg, D. H., Sjövall, J., Sjövall, K., and Turner, D. A. (1965). Measurement of human serum bile acids by gasliquid chromatography. Journal of Lipid Research, 6, 182-192.

Schalm, S. W., Henegouwen, Van Berge, G. P. van, Hofmann, A. F., Cowen, A. E., and Turcotte, J. (1977). Radioimmunoassay of bile acids; development, validation, and a preliminary application of an assay for conjugates of chenodeoxycholic acid. Gastroenterology, 73, 285-290.

Schwartz, H. P., von Bergmann, K., and Paumgartner, G. (1974). A simple method for the estimation of bile acids in serum. Clinica Chimica Acta, 50, 197-206.

Sherlock, S., and Walshe, V. (1948). Blood cholates in normal subjects and in liver disease. Clinical Science, 6, 223-234.

Simmonds, W. J., Korman, M. G., Go, V. L. W., and Hofmann, A. F. (1973). Radioimmunoassay of conjugated cholyl bile acids in serum. Gastroenterology, 65, 705-711.

Spenney, J. G., Johnson, B. J., Hirschowitz, B. I., Mihars, A. A., and Gibson, R. (1977). An ${ }^{125}$ I radioimmunoassay for primary conjugated bile salts. Gastroenterology, 72, 305-311.

Stiehl, A. (1974). Bile salt sulphates in cholestasis. European Journal of Clinical Investigation, 4, 59-63.

Thjodleifsson, B., Barnes, S., Chitranukroh, A., Billing, B. H., and Sherlock, S. (1977). Assessment of the plasma disappearance of cholyl- ${ }^{114} \mathrm{C}$ glycine as a test of hepatocellular disease. Gut, 18, 697-702.

Winkel, P., Ramsøe, K., Lyngbye, J., and Tygstrup, N. (1975). Diagnostic value of routine liver tests. Clinical Chemistry, 21, 71-75. 